\title{
Reproductive strategies of two Curimatidae species in a Mogi Guaçu impoundment, upper Paraná River basin, São Paulo, Brazil
}

\author{
Alexandre Peressin, Cristina da Silva Gonçalves and Francisco Manoel de Souza Braga
}

\begin{abstract}
Considering that reproduction studies are fundamental to understand the life cycle of organisms, this study aimed to investigate the reproductive strategies of saguirus Cyphocharax nagelii and Steindachnerina insculpta in a dam of Mogi Guaçu River, (SP). Specimens were collected between August 2005 and July 2006 using gillnets with mesh sizes ranging from 1.5 to $5.0 \mathrm{~cm}$ between adjacent knots. Reproductive dynamics, body condition, reproductive period, spawning type and fecundity were analyzed in both species. The body condition reflected the reproductive dynamics, and differed significantly between the wet and dry seasons. During the dry season, the feeding activity and the accumulation of fat in the visceral cavity were higher. The reproductive period of both species covered the months between August and February, with peaks in October and December, and the distribution of the diameters of oocytes allowed to classify them as total spawners. The fecundity increased with weight and length, reaching 28,800 and 27,906 oocytes per female for C. nagelii and S. insculpta, respectively, whereas the amplitude of oocyte diameters varied between $50-1025 \mu \mathrm{m}$ for the former and 75-975 $\mu \mathrm{m}$ for the later species. Taking into account that species with different reproductive strategies also respond differently to environmental impacts, our findings provide important information to subsidize management plans for these curimatid species.
\end{abstract}

Considerando que o conhecimento da reprodução é fundamental para a compreensão do ciclo de vida dos organismos, este trabalho buscou avaliar as estratégias reprodutivas dos saguirus Cyphocharax nagelii e Steindachnerina insculpta em um represamento no rio Mogi Guaçu (SP). Os exemplares foram coletados entre agosto de 2005 e julho de 2006 com redes-de-espera (com tamanhos de malha variando entre 1,5 e 5,0 cm entre nós adjacentes). A dinâmica reprodutiva, a condição corporal, o período reprodutivo, o tipo de desova e a fecundidade foram os parâmetros reprodutivos analisados nas duas espécies. A condição corpórea refletiu a dinâmica reprodutiva, sendo significativamente diferente entre os períodos seco e chuvoso. Durante o período seco, a atividade alimentar e o acúmulo de gordura na cavidade visceral foram maiores. O período reprodutivo das duas espécies abrangeu os meses entre agosto e fevereiro, com picos em outubro e dezembro, e a distribuição dos diâmetros de ovócitos permitiu classificá-las como desovadoras totais. A fecundidade aumentou com o peso e com o comprimento, atingindo em média 28.800 e 27.906 ovócitos por fêmea, para $C$. nagelii e $S$. insculpta, respectivamente, ao passo que a amplitude de diâmetros ovocitários variou de 50 a $1.025 \mu \mathrm{m}$ para a primeira e de 75 a $975 \mu \mathrm{m}$ para a segunda espécie. Considerando que espécies com estratégias reprodutivas diferentes também respondem de modos diferentes aos impactos ambientais, as informações obtidas são importantes subsídios para nortear medidas de manejo para essas espécies de curimatídeos.

Key words: Cyphocharax, Fecundity, Spawning, Steindachnerina, Toothless characin.

\section{Introduction}

The ichthyofauna in the upper Paraná River basin in Brazil is very diversified (Langeani et al., 2007) and has been suffering a series of human impacts, such as dam construction, which is present in almost all of major rivers of São Paulo (SP) state, in southeastern Brazil (Agostinho et al., 2007). The damming of rivers transforms the aquatic environment (Castro \& Arcifa, 1987; Nilsson et al., 2005), which favors some fish species, but has deleterious effects in others. Species that are able to adapt to the lentic environment created by the dam can be benefited by the change, becoming abundant or even dominant in these environments, such as fishes of Curimatidae family (Castro \& Arcifa, 1987; Barbieri, 1995; Loureiro-Crippa \& Hahn, 2006; Novakowski et al., 2007; Gonçalves \& Braga, 2008).

Members of Curimatidae family (order Characiformes) are popularly known as saguirus, birus or manjubas, and comprises eight genera and 97 species widely distributed on Neotropical region (South America and Southeast Central America). The two studied species herein, Cyphocharax

Universidade do Estado de São Paulo (UNESP), Departamento de Zoologia, Instituto de Biociências. Avenida 24-A, 1515, 13.506-900 Rio Claro, SP, Brazil. alex_peressin@yahoo.com.br(AP) 
nagelii (Steindachner, 1881) and Steindachnerina insculpta (Fernández-Yépez, 1948), occurs in upper Paraná River basin (Brazil) (Vari, 2003). Curimatids have adaptations to iliophagous feeding habit (i.e. teeth are absent in adults, species have long intestines and many gill rakers) to provide greater efficiency in the use of the fine particulate organic matter present in sediment (Bowen, 1983; Vari, 1989; Silva et al., 2005). Most curimatids are small-sized and fusiform-bodied (Vari, 2003). Detritivorous fishes play an important role in environments they inhabit, accelerating the recycling of organic matter (Bowen, 1983; Sazima \& Caramaschi, 1989; Fugi et al., 1996; Giora \& Fialho, 2003). Besides its ecological importance, these species are an important fishery resource in certain regions, such as Amazon (Araujo-Lima et al., 1986), and also represents an important food resource to piscivorous fish (Novakowski et al., 2007). Regarding reproduction, curimatids may have long reproductive periods and parceled spawning with peaks occurring in warmer and wet months (Romagosa et al., 1984; Barbieri, 1995; Holzbach et al., 2005; Ribeiro et al., 2007). However, some species perform short reproductive migrations (Godoy, 1975) and have total spawning (Alvarenga et al., 2006).

Reproduction studies are important to understand the life cycle of fishes, mainly in order to establish management policies of fishery resources and species conservation (Vazzoler \& Menezes, 1992; Casimiro et al., 2011). In this context, this study aimed to investigate the reproductive strategies of two curimatids, Cyphocharax nagelii and Steindachnerina insculpta, in the reservoir of a Small Hydro Power (SHP) of Mogi Guaçu River (SP), upper Paraná River basin.

\section{Material and Methods}

\section{Study area}

The SHP Mogi Guaçu (22 $\left.21^{\prime} \mathrm{S} 46^{\circ} 51^{\prime} \mathrm{W}\right)$ is located in Mogi Guaçu municipality, São Paulo state. This reservoir has $5.73 \mathrm{~km}^{2}$ of area, extension of $8 \mathrm{~km}$ and $32.89 \times 10^{6} \mathrm{~m}^{3}$ of volume to supply water to neighboring municipalities and to generate approximately 7.2 MW of electricity. Other characteristics are: barrage with extension of $150 \mathrm{~m}$, water fall with $7 \mathrm{~m}$, two installed turbines, four flood gates and a fish ladder with 21 step-tanks for fish passage (Brandimarte et al., 2005; AESTietê, 2011). At the sampled site, bottom is muddy or sandmuddy, maximum depth is around $5 \mathrm{~m}$ and the border vegetation is dominated by sugar cane and pastures (Gonçalves \& Braga, 2008). The analysis of temperature and rainfall in the studied area (average of 30 years, 1971 to 2005, data from meteorological station D4-100 located at Campininha farm) allowed the determination of dry (April to September) and wet (October to March) periods.

\section{Sampling methods and data processing}

Samples were taken between August 2005 and July 2006, comprising six samples (August, October and December 2005; February, April and June 2006). Sampling effort was standardized using gillnets with $40 \mathrm{~m}$ in length and with mesh sizes of 1.5, 2.0, 2.5, 3.0, 4.0 and $5.0 \mathrm{~cm}$ between adjacent knots, which were set in the afternoon and removed in the morning of the following day. Fishes were fixed in formalin $10 \%$ and kept in alcohol solution $70 \%$. Voucher specimens were stored in the fish collection of Department of Zoology and Botany, IBILCE/UNESP, Brazil (C. nagelii DZSJRP 13267; S. insculpta DZSJRP 13266-68).

A total of 524 individuals of $C$. nagelii and 250 individuals of $S$. insculpta were analyzed, comprising 774 specimens. In the laboratory, the following data were obtained of each specimen: sex, standard length $(\mathrm{mm})$ and total weight $(\mathrm{g})$. Stomachs were visually classified according to its repletion: 1 (empty), 2 (partially full) and 3 (full). Visceral cavity was visually analyzed: 1 (no fat), 2 (partially with fat) and 3 (full). Mature ovaries were visually defined considering color, transparency, vascularization of gonads, oocytes appearance and visualization. Then, ovaries were weighted and kept in Gilson's solution until fecundity analysis (Vazzoler, 1996).

\section{Data analysis}

Reproductive dynamics. Reproductive dynamics was analyzed to each species by variations of stomach repletion and fat accumulation on visceral cavity. The chi-square test was used in order to verify the dependence of these variables between dry and wet periods (Zar, 2010).

The gonadosomatic relationship (GSR) was obtained: GRS $=W_{O} / W_{T} * 100$, where $W_{O}$ is the ovarian weight $(\mathrm{g})$, and $W_{T}$ is the total weight $(\mathrm{g})$ of the fish (Vazzoler, 1996). The reproductive period was determined analyzing the frequency of mature females bimonthly and GSR mean values. In order to verify the correspondence of mature females bimonthly, a chi-square test was applied (Zar, 2010).

Body condition. An analysis of covariance was performed to evaluate differences in weight (dependent variable) between species, periods (dry and wet) and gender (factors), using the standard length as covariate (Zar, 2010), following the model: $\log \left(W_{i j}\right)=\mu+S_{i}+\beta_{i}\left(\log L_{i j}-\log L_{i}\right)+\varepsilon_{i j}$, where $W_{i j}$ is the total weight of the individual $j$ in sex i (male or female), $\mu$ is the population average, $S_{i}$ is the effect of $\operatorname{sex} i, L_{i j}$ is the standard length of individual $j$ in sex $i, L_{i}$ is the average standard length of sex $i$ and $\varepsilon_{i j}$ is the random error associated to individual $j$ in sex $i$. The objective was to determine whether, for the same length, the total weight varied between species, periods (dry and wet) or gender. Body-length difference between gender was verified by Kolmogorov-Smirnov test (Lilliefors test was used to check the normality of data and indicated a non-normal distribution). The level of significance was $\alpha=5 \%$ in all analyses (Zar, 2010).

Fecundity and spawning type. To evaluate fecundity, 121 and 47 pairs of mature ovaries of $C$. nagelii and S. insculpta were analyzed, respectively, using the volumetric method (Vazzoler, 1996 modified). The dissociated oocytes were placed in an Erlenmeyer flask with a constant volume of $70 \%$ alcohol (S). After shaking the flask, a sample of $2 \mathrm{ml}(s)$ was taken with a 
Stempel pipette. The counting of vitellogenic oocytes (perinucleolar oocytes were not considered) was performed under a stereomicroscope (40x magnification). The total number of oocytes $(N)$ was estimated assuming: $N=(S * n)$ / $s$, in which $S$ is the volume of solution containing the oocytes in suspension, $n$ is the number of vitellogenic oocytes, and $s$ is the volume of a sample with $2 \mathrm{ml}$ from each pair of ovaries analyzed. A t-test was performed to assess differences in fecundity between species (Zar, 2010). Subsequently, 100 oocytes were randomly selected and measured with an ocular micrometer (10x magnification). A Mann-Whitney test was performed to assess differences in oocytes diameters between species. For each gonad in which mature oocytes were counted and measured, a frequency distribution graph of oocytes diameters was constructed. These charts were compared and those with the same modal diameter were grouped. The frequency distribution of oocytes diameters of ovaries was graphically analyzed to determine the spawning type (total or multiple).

The population fecundity (Vazzoler, 1981) was estimated by correlating the fecundity with total weight and also with standard length, according to the expression: $F=A+B X$, where $F$ is fecundity, $X$ is the explanatory variables (weight or length), $A$ the numerical value of the intercept, and $B$ is the slope, estimated by the method of least squares after logarithmic transformation of the data (Sparre \& Venema, 1997).

\section{Results}

\section{Reprodutive dynamics}

Significant differences were found on stomach repletion and fat accumulation degrees between dry and wet seasons to $C$. nagelii $\left(\chi^{2}=11.08, \mathrm{df}=2, \mathrm{p}<0.05 ; \chi^{2}=265.12, \mathrm{df}=2, \mathrm{p}\right.$ $<0.05$, respectively) and S. insculpta $\left(\chi^{2}=34.37, \mathrm{df}=2, \mathrm{p}<\right.$ $0.05 ; \chi^{2}=148.4, \mathrm{df}=2, \mathrm{p}<0.05$, respectively). Both species had higher frequency of full stomachs during the dry period (Fig. 1). Fat acumulation was low during the wet period, suggesting that fat accumulated during the period of highest feeding activity (dry season) was consumed in the reproductive season (Fig. 2).

Despite differences in the GRS peaks, C. nagelii showed a larger reproductive period covering both dry (August) and wet seasons (October and December) $\left(\chi^{2}=83.4, \mathrm{df}=5, \mathrm{p}<\right.$ $0.0001)$, whereas $S$. insculpta concentrated its reproductive activity in wet season (October and December) $\left(\chi^{2}=261.1, \mathrm{df}\right.$ $=5, \mathrm{p}<0.0001$ ) (Fig. 3 ). The maximum GRS values obtained was $23.8 \%$ and $25.5 \%$, to C. nagelii and S. insculpta, respectively, and the bimonthly variation of GRS for each species are presented in Fig. 3.

\section{Body condition}

The body condition was assessed to identify differences in the relationship between weight and length of species (Table 1). There was no significant interaction between species and the covariate length, which indicate that lengthweight relationship is the same to C. nagelii and S. insculpta $(\mathrm{p}=0.592)$, but body condition was significantly different between dry and wet periods $(\mathrm{p}<0.05)$. There was no significant difference in the length-weight relationship between genders (Table 2), although females were larger than males in C. nagelii $\left(\right.$ mean $_{\text {(females) }}=106.2 \pm 14.3 \mathrm{~mm} \mathrm{sd}$, mean $_{\text {(males) }}=102.4 \pm 14.1 \mathrm{~mm} \mathrm{sd}, \mathrm{D}=0.1251, \mathrm{p}<0.05$ ) and in $S$. insculpta $\left(\right.$ mean $_{\text {(females) }}=101.4 \pm 10.6 \mathrm{~mm} \mathrm{sd}$, mean (males) $=101$ $\pm 10.6 \mathrm{~mm} \mathrm{sd}, \mathrm{D}=0.1850, \mathrm{p}<0.05)$.

\section{Fecundity and spawning type}

Fecundity was estimated from the analysis of mature ovaries of C. nagelii and S. insculpta, and ranged from 3,935 to 43,659 oocytes (mean $=17,560 \pm 9,106.32 \mathrm{sd}$ ), and from 10,964 to 42,786 oocytes $($ mean $=26,815 \pm 8,333.47 \mathrm{sd})(\mathrm{t}=-4.64, \mathrm{df}=166, \mathrm{p}<$ 0.0001 ), for each species, respectively.

The amplitude of oocytes diameters ranged from 50 to $1,075 \mu \mathrm{m}$ to C. nagelii and from 75 to $975 \mu \mathrm{m}$ to $S$. insculpta $(\mathrm{U}=590, \mathrm{p}<0,01)$. In the oocyte's distribution of C. nagelii (Fig. 4) it is possible to note a continuous gradient of development (Fig. 4). Group I show two modes: one mode is

\section{Cyphocharax nagelii}

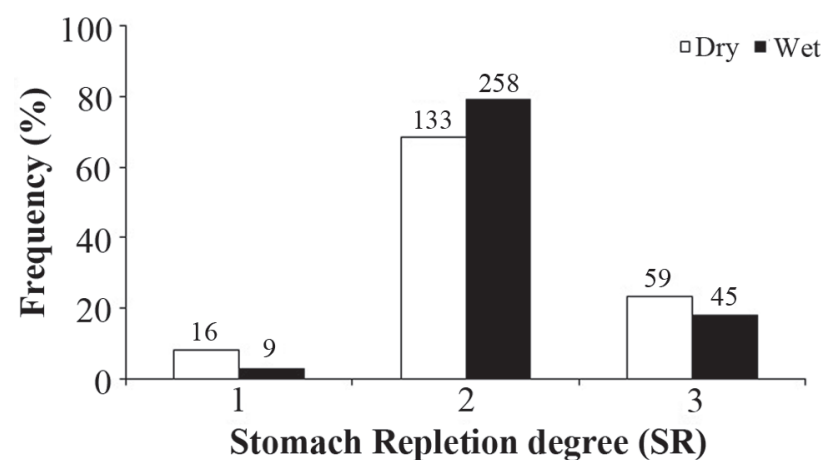

\section{Steindachnerina insculpta}

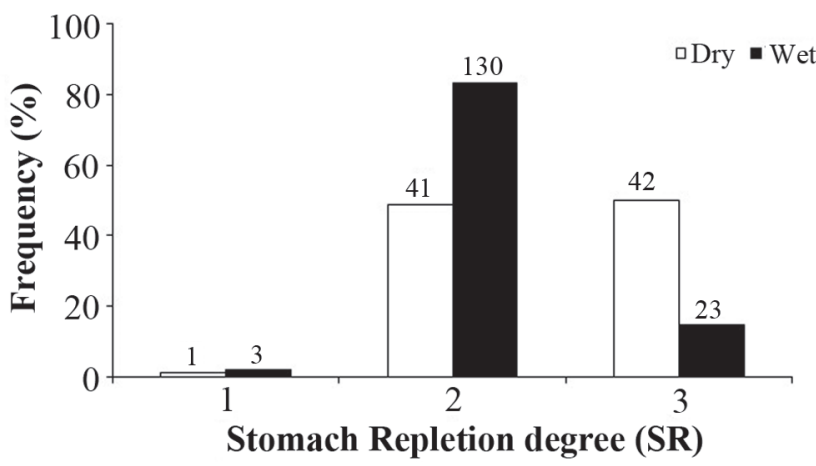

Fig. 1. Stomach repletion degree (SR) of Curimatidae species during dry and wet seasons. 1: empty stomachs, 2: partially filled stomachs, and 3: full stomachs. Values above bars represent the absolute number of stomach repletion degrees obtained in each period. 

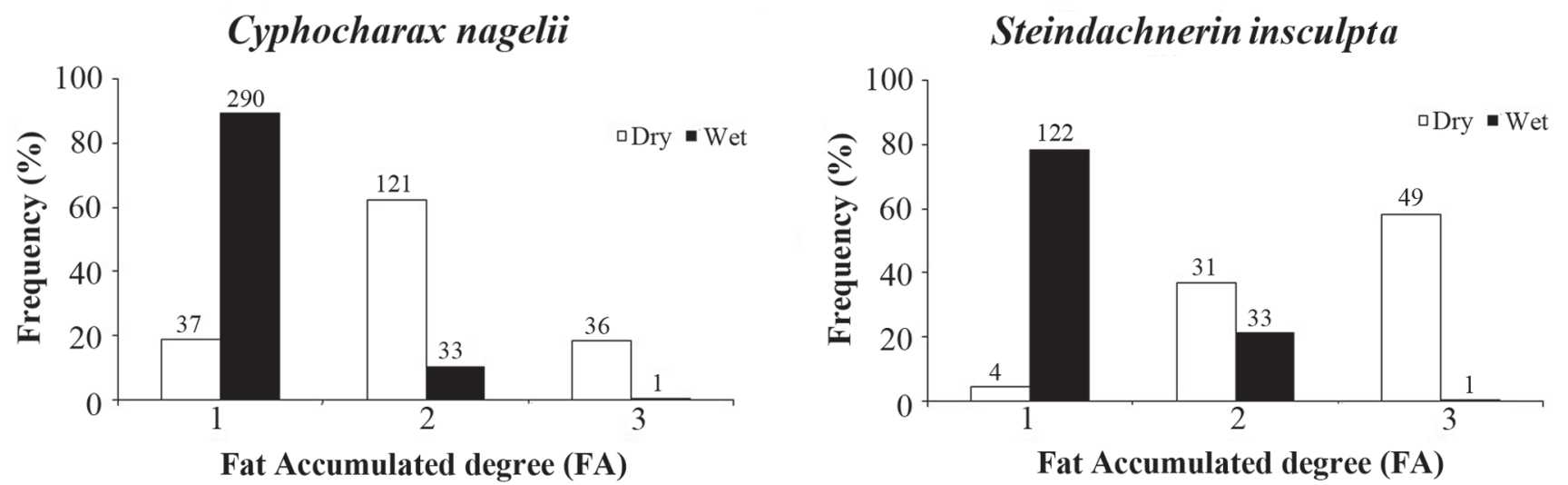

Fig. 2. Fat accumulated degree (FA) of Curimatidae species during dry and wet seasons. 1: no fat, 2: visceral cavity partially filled with fat, and 3: visceral cavity completely filled with fat. Values above bars represent the absolute numbers of fat accumulated degrees obtained in each period.

represented by oocytes with smaller diameters, and the other mode represented by oocytes with larger diameter. The modal oocyte diameter gradually increases from the first to the third group of distribution. Cyphocharax nagelii's GSR follows this trend, increasing steadily from group I to group III (Table 3). Steindachnerina insculpta presented the same pattern of oocytes distribution, similar to group III of C. nagelii, although the smaller oocytes were less conspicuous (Fig.5).

Fecundity (F) increased with weight (W) and length (L) in C. nagelii $(\mathrm{F}=10616+287.42 \mathrm{~W}$ and $\mathrm{F}=-14383+326.06 \mathrm{~L})$, and in S. insculpta $(\mathrm{F}=-6083.7+656.9 \mathrm{~W}$ and $\mathrm{F}=-40603.4+$ 641.3L) (Fig. 6).

\section{Discussion}

Fish are able to adapt to environments in which biotic and abiotic conditions can vary widely, allocating energy by feeding that, in turn, is converted to offspring, increasing their reproductive success (Vazzoler, 1996). In general, fat accumulation occurs in the dry period, when the foraging activity is higher and the gonads are resting, whereas fat levels decrease later, coinciding with the maturation of the gonads and subsequent spawning (Alvarenga et al., 2006; Braga et al., 2008; Carmassi et al., 2008; Giora \& Fialho, 2003; Ribeiro et al., 2007).

In the studied area, the body condition of C. nagelii and S. insculpta was not different either between species or between gender, but there were differences between dry and wet seasons. These results indicate that males and females of both species probably use the environmental resources in a similar way. The body condition differences between dry and wet seasons for both species corresponded to their reproductive dynamics, which indicated that feeding activity and fat accumulation were more intense during the dry season. The decrease of feeding activity observed during the wet
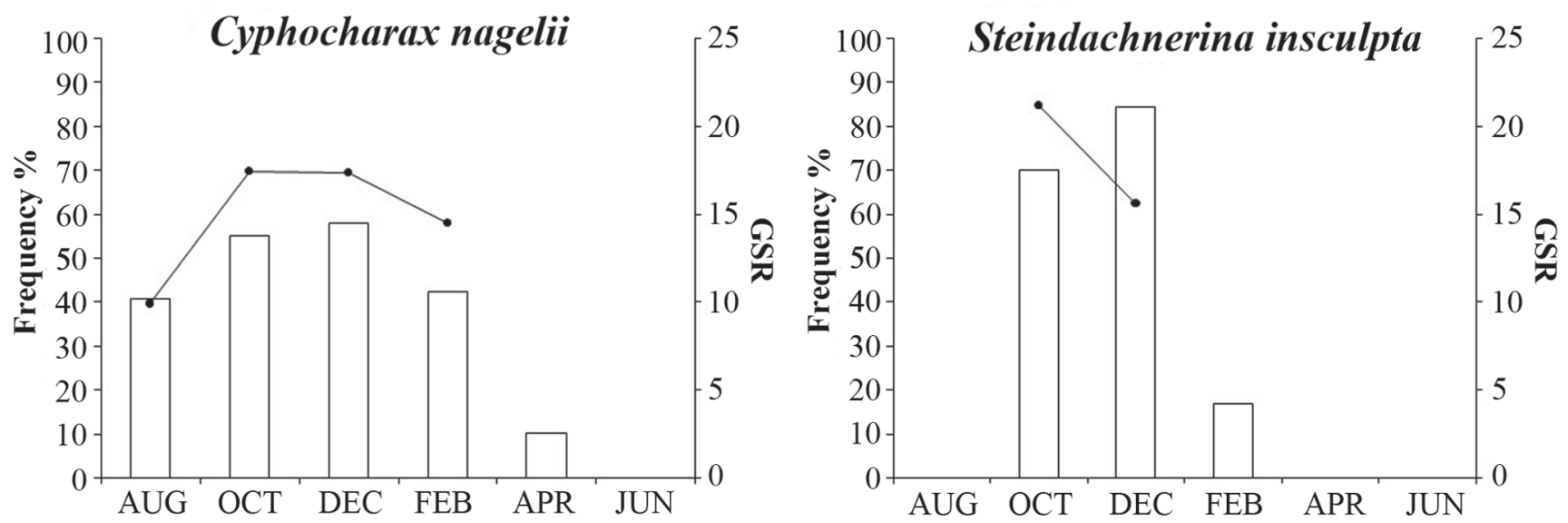

Fig. 3. Proportion of mature females (\%) (columns) and values of gonadossomatic relationship (GSR) (lines) of both studied Curimatidae species between August 2005 and June 2006. Dry period: April-August; wet period: October-February. 
Table 1. Covariance analysis for the natural logarithm $(\mathrm{Ln})$ of total weight (TW - dependent variable) in relation to the following factors: standard length (SL - covariate), species (Cyphocharax nagelii and Steindachnerina insculpta levels), and periods (dry and wet levels) $\left(n=695 ; r^{2}=0.93\right)$.

\begin{tabular}{lccccc}
\hline Sources of variation & $\begin{array}{c}\text { Sum of } \\
\text { Squares }\end{array}$ & df & $\begin{array}{c}\text { Mean } \\
\text { Square }\end{array}$ & F & P \\
\hline LnSL & 50.823 & 1 & 50.823 & 4855.286 & $<0.001$ \\
Species & 0.003 & 1 & 0.003 & 0.241 & 0.624 \\
Periods & 0.052 & 1 & 0.052 & 4.956 & 0.026 \\
LnSL*Species & 0.003 & 1 & 0.003 & 0.288 & 0.592 \\
LnSL*Periods & 0.054 & 1 & 0.054 & 5.172 & $\mathbf{0 . 0 2 3}$ \\
Species*Periods & 0.002 & 1 & 0.002 & 0.189 & 0.664 \\
LnSL*Species*Periods & 0.002 & 1 & 0.002 & 0.197 & 0.657 \\
Residual & 7.191 & 687 & 0.010 & & \\
\hline
\end{tabular}

season for both species may be due to compression of internal organs caused by the gonads growth (Slotte, 1999), or due to rainfall that makes difficult the sedimentation of organic matter in the water (Teixeira \& Gurgel, 2004), and could compromise feeding of curimatid species.

The GSR index indicates the degree of ovarian development, therefore, more developed ovaries present higher GSR values. This relationship between oocytes development and GSR supports the ovarian dynamics due to the accumulation of yolk in oocytes (West, 1990). According to the bimonthly frequency of mature females and GSR values, the reproductive period of the two studied species was concentrated in the wet season, which has been also reported to other curimatids (Braga, 1990; Carmassi et al., 2008). Moreover, Godoy (1975) observed C. nagelii and S. insculpta performing massive reproductive migrations in Cachoeira de Emas (located downstream the studied area herein), with spawning occurring between November and January.

The ovaries have a seasonal cycle of oocytes development, associated with the vegetative functions of fish (Nikolsky, 1963; Nikolskii, 1969). Inside the ovaries, the germinal epithelium is in constant cellular activity producing oocytes, which results in the presence of oocytes at different stages of development within the same ovary (Wallace \& Selman, 1981). The ovaries examined in this study were considered mature, but oocytes were at different stages of development (less developed and

Table 2. Covariance analysis for the natural logarithm $(\mathrm{Ln})$ of total weight (TW - dependent variable) in relation to standard length (SL - covariate) and gender (males and females) factors for Cyphocharax nagelii and Steindachnerina insculpta.

\begin{tabular}{lcccccc}
\hline Sources of variation & \multicolumn{3}{c}{$\begin{array}{c}\text { Cyphocharax } \\
\text { nagelii }\end{array}$} & \multicolumn{3}{c}{$\begin{array}{c}\text { Steindachnerina } \\
\text { insculpta }\end{array}$} \\
& $\left(\mathrm{n}=477, \mathrm{r}^{2}=0.95\right)$ & \multicolumn{2}{c}{$\left(\mathrm{n}=218, \mathrm{r}^{2}=0.91\right)$} \\
\cline { 2 - 7 } & $\mathrm{df}$ & $\mathrm{F}$ & $\mathrm{P}$ & $\mathrm{df}$ & $\mathrm{F}$ & $\mathrm{P}$ \\
\hline LnSL & 1 & 7456.831 & $<0.001$ & 1 & 1724.173 & $<0.001$ \\
Gender & 1 & 0.753 & 0.386 & 1 & 0.366 & 0.546 \\
Gender * LnSL & 1 & 1.010 & 0.315 & 1 & 0.518 & 0.473 \\
Residual & 473 & & & 214 & & \\
\hline
\end{tabular}

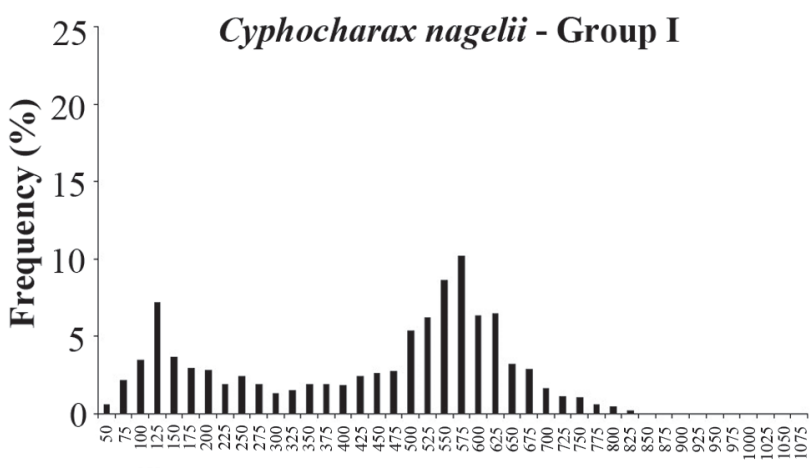

Oocytes diameters $(\mu \mathrm{m})$

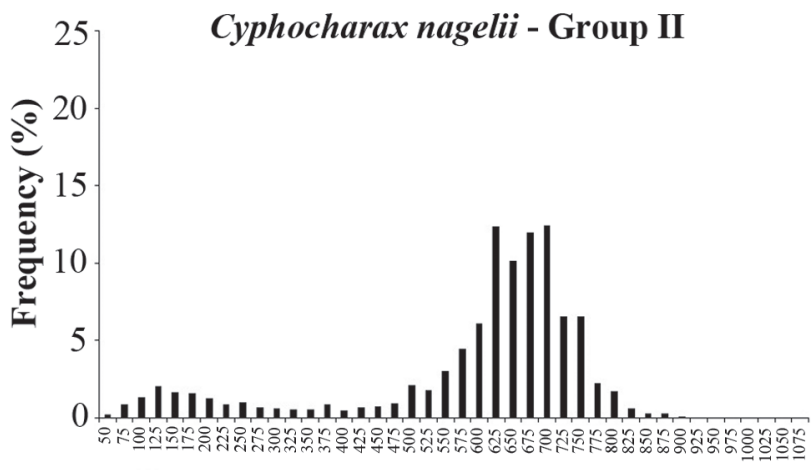

Oocytes diameters $(\mu \mathrm{m})$

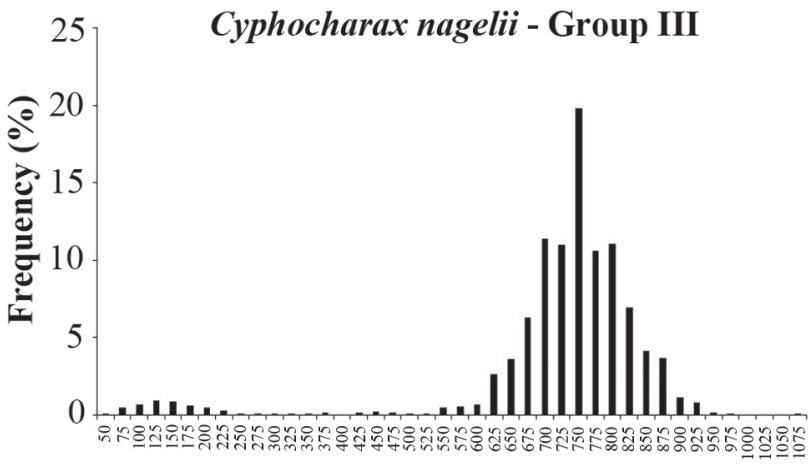

Oocytes diameters $(\mu \mathrm{m})$

Fig. 4. Frequency distribution of oocytes diameters of Cyphocharax nagelii according to the developmental groups.

Table 3. Number of mature females analyzed $(\mathrm{N})$, mean fecundity (and range), and mean gonadosomatic relationship (GSR) to Curimatidae species.

\begin{tabular}{lcccc}
\hline \multicolumn{1}{c}{ Species } & Groups & $\mathrm{N}$ & Fecundity & GSR \\
\hline Cyphocharax & I & 16 & $18,000(8,550-35,775)$ & 8.27 \\
nagelii & II & 78 & $20,112(4,800-44,175)$ & 13.07 \\
Steindachnerina & III & 27 & $25,488(10,800-42,825)$ & 18.22 \\
insculpta & & 47 & $26,815(10,964-42,786)$ & 17.5 \\
\hline
\end{tabular}




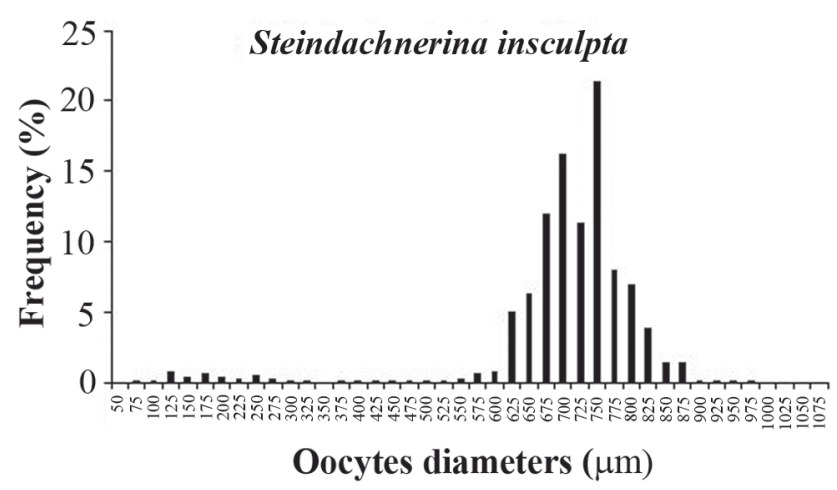

Fig. 5. Frequency distribution of oocytes diameters of Steindachnerina insculpta.

more developed). The less developed oocytes (non-vitellogenic) occurred in smaller proportion, when compared to mature oocytes or in the process of maturation, and were not considered. The spawning type is determined by the interaction between the dynamics of oocyte development, the frequency of spawning within a breeding season and the frequency of this events during his life (Araujo, 2009). Vazzoler (1996) described the dynamics of oocytes development as follow: (i) synchronous in one group (ii) synchronous in two groups, and (iii) synchronous in more than two groups. In the second case, in each reproduction period, two batches of oocytes are evident within the ovaries: the reserve stock and the batch of oocytes that will mature and be eliminated during spawning. In this study, oocyte development groups of C. nagelii showed a steady increase in the modal diameter, with a consequent disappearance of the smaller batch of oocytes (more evident in group I), leaving only one batch of oocytes in group III. Romagosa et al. (1984), analyzing the curimatid Curimata gilberti (= Cyphocharax gilberti), showed that oocytes with diameters up to $200 \mu \mathrm{m}$ compose the oocytes group that is coming out of the lot stock, and does not participate in spawning. In the present work, the smaller batch of oocytes present in groups I and II are located precisely in this size range. The continuous increase in the GSR from group I to group III also indicates further development of the ovaries from group I to group III, since the GSR is indicative of the stage of maturity. In $S$. insculpta, only one group was formed, with characteristics very similar to group III of $C$. nagelii, including GSR values. According to these findings, we concluded that $C$. nagelii and $S$. insculpta presented one group of oocytes (not considering the batch stock). If the batch stock had been considered in our analysis, both species should share the same type of synchronous development in two groups, as described by Vazzoler (1996). As total spawners are species that mature and spawn only one batch of mature oocytes (i.e. ignoring the batch stock) per spawning season and multiple spawners release its oocytes in more than one batch during the spawning season (e.g. Godinho et al. 2010), we concluded that C. nagelii and $S$. insculpta are total spawners in the studied area.

West (1990) stated that the type of oocytes development is not necessarily an immutable characteristic of each species. Thus, the spawning type presented by a species reflects the
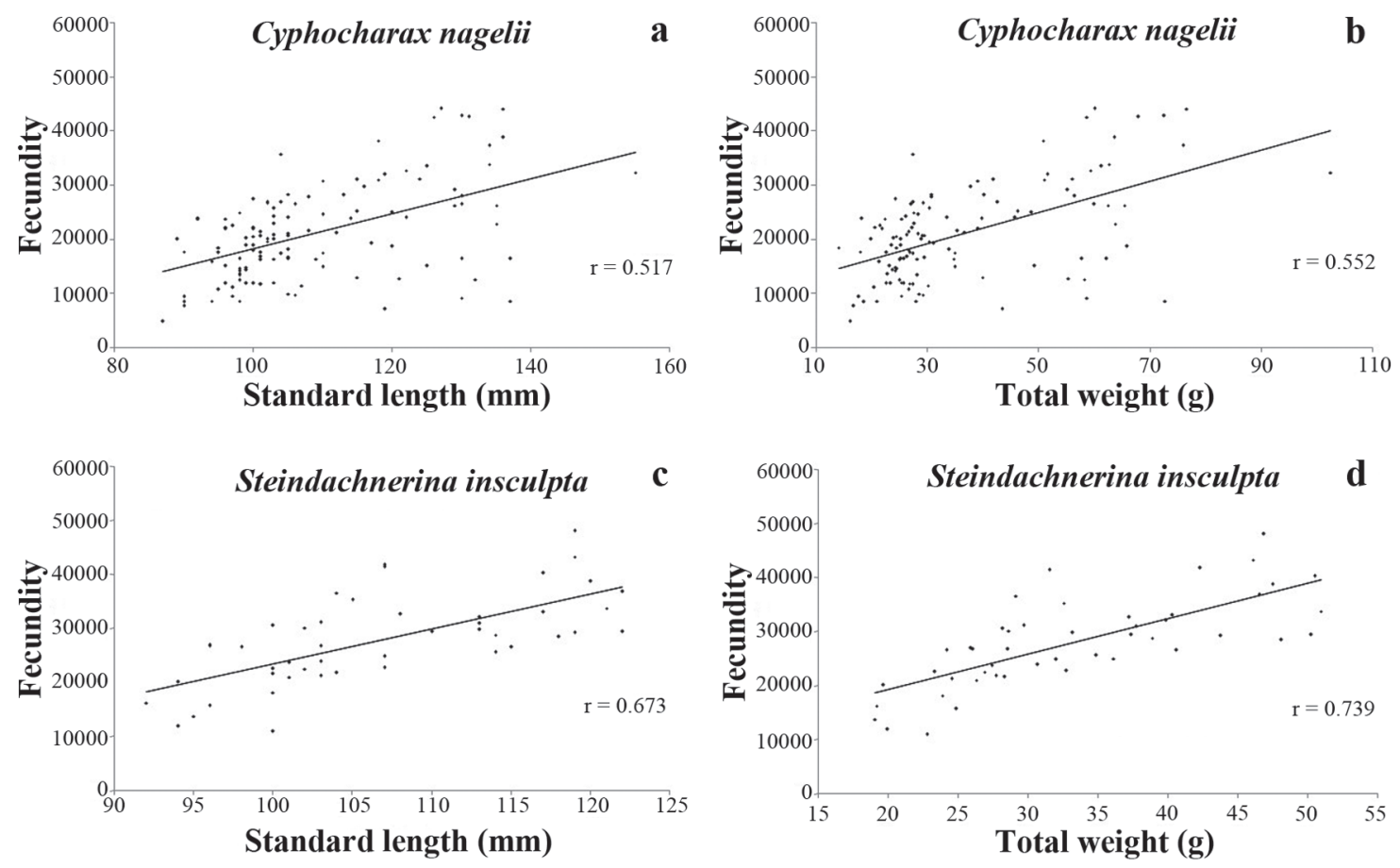

Fig. 6. Fecundity-standard length $(\mathrm{mm})$ and fecundity-total weight $(\mathrm{g})$ relationships to both studied Curimatidae species. 
local characteristics of the environment it inhabit. For example, other studies with Curimatidae species indicated that they can be multiple spawners (Romagosa et al., 1984; Hartz et al., 1994; Barbieri, 1995; Holzbach et al., 2005; Ribeiro et al., 2007; Petesse et al., 2007) or total spawners (Alvarenga et al., 2006; Carmassi et al., 2008), but all these studies agreed that spawning peaks occurs during the months of highest rainfall and temperature, similar to our findings.

The high fecundity found in this study correspond to those reported in literature for other species of the family Curimatidae, which can vary from 4,380 to 100,130 oocytes (Nomura \& Taveira, 1979; Romagosa et al., 1984; Hartz et al., 1994; Schifino et al., 1998; Sampaio \& Sato, 2007), as well as the oocyte diameters, that ranges from 427 to $4,789 \mu \mathrm{m}$ in high Paraná River basin fishes (Vazzoler, 1996). For many authors, fecundity and oocyte diameters do not necessarily depend on fish size, but on reproductive tactics (Vazzoler, 1996; Araujo, 2009; Casimiro et al., 2011). Fecundity and oocyte diameters are reproductive traits that have many variations in inter- and intraspecific levels, depending on the food availability, how many times the fish spawned, temperature and altitude (Nikolsky, 1963; Hartz et al., 1999). Moreover, the fertility is inversely proportional to the parental care (Lagler et al. 1977), which corresponds to the results obtained here, since Curimatidae species do not perform parental care (Vazzoler, 1996).

There was a correlation between fecundity and length and between fecundity and weight to both Curimatidae species in the present study, which is common for several species (MartinsQueiroz et al., 2008; Agostinho \& Júlio Jr, 1999). The positive correlations between fecundity and length or weight in fishes are evidences that larger females are more fecund, because the fecundity depends mainly on the size of coelomic cavity to accommodate the mature ovaries (Wootton, 1992), since the oocytes size does not increase with the size of the female.

Overall, our findings correspond to those available in the literature for species of Curimatidae family. Although the reproduction is an aspect of the life cycle more studied in fish, information on some reproductive tactics obtained here (e.g. spawning and fecundity) is still scarce (Potts \& Wotton, 1984). Thus, besides filling a gap in knowledge regarding the reproduction of these species, our results may also be useful as a basis for comparison in future studies. Moreover, considering that fishes with different reproductive strategies respond in different ways to environmental impacts (Vazzoler \& Menezes, 1992), our findings can be helpful to guide protection and management plans for these curimatid species.

\section{Acknowledgments}

The authors are grateful to Francisco Langeani for fishes identification, IBAMA for collection permits (02027.000991/ 2005-71), CAPES for dissertation fellowship granted to the second author, FAPESP (2009/52478-6) for grants received by the first author, and Haru Ushisawa Yamamoto for reviewing the English. This paper is part of graduation course of Alexandre Peressin concluded at UNESP (Rio Claro/SP).

\section{Literature Cited}

AES-Tietê. 2011. Pequena Central Hidrelétrica Mogi-Guaçu. Available from: http://www.aestiete.com.br/usinas/Paginas/ PequenaCentralHidrelétricaMogi-Guaçu.aspx (04/08/2011).

Agostinho, A. A., L. C. Gomes \& F. M. Pelicice. 2007. Ecologia e manejo de recursos pesqueiros em reservatórios do Brasil. Maringá, EDUEM, 501p.

Agostinho, A. A. \& H. F. Júlio Jr. 1999. Peixes da bacia do alto rio Paraná. Pp. 374-400. In: Lowe-Mcconnel, R.H. (Ed.). Estudos Ecológicos de Comunidades de Peixes Tropicais (Trads.: Vazzoler, A.E.A. de M., A.A. Agostinho, P. T. M. Cunnhingham). São Paulo, EDUSP.

Alvarenga, É. R., N. Bazzoli, G. B. Santos \& E. Rizzo. 2006. Biologia reprodutiva e alimentação de Curimatella lepidura (Eigenmann \& Eigenmann) (Pisces, Curimatidae) no reservatório de Juramento, Minas Gerais. Revista Brasileira de Zoologia, 23: 314-322.

Araujo, R. B. 2009. Desova e fecundidade em peixes de água doce e marinhos. Revista de Biologia e Ciências da Terra, 9: 25-31.

Araujo-Lima, C., B. R. Forsberg, R. Victoria \& L. Martinelli. 1986. Energy sources for detritivorous fishes in the Amazon. Science, 234: 1256-1258.

Barbieri, G. 1995. Biologia populacional de Cyphocharax modesta (Hensel, 1869) (Characiformes, Curimatidae) da represa do Lobo (Estado de São Paulo) II. Dinâmica da reprodução e influência de fatores abióticos. Boletim do Instituto de Pesca, 22: 57-62.

Bowen, S. H. 1983. Detritivory in neotropical fish communities. Environmental Biology of Fishes, 9: 137-144.

Braga, F. M. S. 1990. Aspectos da reprodução e alimentação de peixes comuns em um trecho do rio Tocantins entre Imperatriz e Estreito, Estados do Maranhão e Tocantins, Brasil. Revista Brasileira de Biologia, 50: 547-558.

Braga, F. M. S., L. M. Gomiero \& U. P. Souza. 2008. Aspectos da reprodução e alimentação de Neoplecostomus microps (Loricariidae, Neoplecostominae) na microbacia do Ribeirão Grande, serra da Mantiqueira oriental (Estado de São Paulo). Acta Scientiarum. Biological Sciences, 30: 455-463.

Brandimarte, A. L., M. Anaya \& G. Y. Shimizu. 2005. Downstream impact of Mogi-Guaçu River damming on the benthic invertebrates (São Paulo State, Brazil). Acta Limnologica Brasiliensia, 17: 27-36.

Carmassi, A. L., A. T. Silva, G. R. Rondineli \& F. M. S. Braga. 2008. Biologia populacional de Cyphocarax modestus (Osteichthyes, Curimatidae) no córrego Ribeirão Claro, município de Rio Claro (SP). Biota Neotropica, 8: 109-114.

Casimiro, A. C. R., D. A. Z. Garcia, F. S. Almeida \& M. L. Orsi. 2011. Reproductive aspects of Moenkhausia intermedia Eigenmann, 1908 (Pisces, Characidae) in the Upper Paraná River Basin, Brazil. International Scholarly Research Network Zoology, 2011: 1-8.

Castro, R. M. C. \& M. S. Arcifa. 1987. Comunidades de peixes de reservatórios no sul do Brasil. Revista Brasileira de Biologia, 47: 493-500.

Fugi, R., N. S. Hahn \& A. A. Agostinho. 1996. Feeding styles of five species of bottom-feeding fishes of the high Paraná river. Environmental Biology of Fishes, 46: 297-307.

Giora, J. \& C. B. Fialho. 2003. Biologia alimentar de Steindachnerina brevipinna (Characiformes, Curimatidae) do rio Ibicuí-Mirim, Rio Grande do Sul, Brasil. Iheringia, Série Zoologia, 93: 277-281.

Godinho, A. L., I. R. Lamas \& H. P. Godinho. 2010. Reproductive ecology of Brazilian freshwater fishes. Environmental Biology of Fishes, 87:143-162. 
Godoy, M. P. 1975. Peixes do Brasil - Subordem Characoidei: Bacia do rio Mogi Guassu. Piracicaba Franciscana, 846p.

Gonçalves, C. S. \& F. M. S. Braga. 2008. Diversidade e ocorrência de peixes na área de influência da UHE Mogi Guaçu e lagoas marginais, bacia do alto rio Paraná, São Paulo, Brasil. Biota Neotropica, 8: 103-114.

Hartz, S. M., A. C. Peret \& G. Barbieri. 1999. Reproduction of Gymnogeophagus lacustris, a cichlid endemic to southern Brazil. Ichthyology Exploration Freshwaters, 10: 247-253.

Hartz, S. M., A. G. Martins \& A. C. Peret. 1994. Fecundidade de Cyphocharax voga (Hensel, 1869) na lagoa Emboaba, Rio Grande do Sul, Brasil (Characiformes, Curimatidae). Iheringia, Série Zoologia, 76:161-165.

Holzbach, A. J., G. Baumgartner, F. Bergmann, L. B. Rezende Neto, D. Baumgartner, P. V. Sanches \& E. A. Gubiani. 2005. Caracterização populacional de Steindachnerina insculpta (FernándezYépez, 1948) (Characiformes, Curimatidae) no rio Piquiri. Acta Scientiarum. Biological Sciences, 27: 347-353.

Lagler, K. F., J. E. Bardach \& R. R. Miller. 1977. Ichthyology. New York: Wiley, $\mathrm{xv}+506$.

Langeani, F., R. M. C. Castro, O. T. Oyakawa, O. A. Shibatta, C. S. Pavanelli \& L. Casatti. 2007. Diversidade da ictiofauna do Alto Rio Paraná: composição atual e perspectivas futuras. Biota Neotropica, 7: 181-197.

Loureiro-Crippa, V. E. \& N. S. Hahn. 2006. Use of food resources by the fish fauna of a small reservoir (rio Jordão, Brazil) before and shortly after its filling. Neotropical Ichthyology, 4: 357-362.

Martins-Queiroz, M.F., L. A. F. Mateus, V. Garutti \& P. C. Venere. 2008. Reproductive biology of Triportheus trifurcatus (Castelnau, 1855) (Characiformes: Characidae) in the middle rio Araguaia, MT, Brazil. Neotropical Ichthyology, 6: 231-236.

Nikolsky, G. V. 1963. The ecology of fishes. London, Academic Press, 353p.

Nikolskii, G. V. 1969. Theory of fish population dynamics: as the biological background for rational exploitation and management of fishery resources. Edinburgh, Oliver and Boyd Ltd, 321p.

Nilsson, C., C. A. Reidy, M. Dynesius \& C. Revenga. 2005. Fragmentation and flow regulation of the world's large river systems. Science, 308: 405-408.

Nomura, H. \& A. C. D. Taveira. 1979. Biologia do saguiru, Curimatus elegans Steindachner, 1874 do rio Mogi Guaçu, São Paulo (Osteichthyes, Curimatidae). Revista Brasileira de Biologia, 39: 331-339.

Novakowski, G. C., N. S. Hahn \& R. Fugi. 2007. Alimentação de peixes piscívoros antes e após a formação do reservatório de Salto Caxias, Paraná, Brasil. Biota Neotropica, 7: 1-6.

Petesse, M. L., M. Petrere Jr. \& R. J. Spigolon. 2007. The hydraulic management of the Barra Bonita reservoir (SP, Brazil) as a factor influencing the temporal succession of its fish community. Brazilian Journal of Biology, 67: 433-445.

Potts, G. W. \& R. J. Wootton. 1984. Fish reproduction: strategies and tactics. San Diego, Academic Press.

Ribeiro, V. M. A., G. B. Santos \& N. Bazzoli. 2007. Reproductive biology of Steindachnerina insculpta (Fernandez-Yépez) (Teleostei, Curimatidae) in Furnas reservoir, Minas Gerais, Brazil. Revista Brasileira de Zoologia, 24: 71-76.

Romagosa, E., H. M. Godinho \& M. Y. Narahara. 1984. Tipo de desova e fecundidade de Curimatus gilberti (Quoy \& Gaimard, 1824) da represa de Ponte Nova, alto Tietê. Revista Brasileira de Biologia, 44: 1-8.
Sampaio, E. V. \& Y. Sato. 2007. Desova induzida e aspectos reprodutivos de Curimatella lepidura (Eig. \& Eig., 1889) (Osteichthyes, Characiformes), espécie endêmica da bacia do rio São Francisco. Revista Brasileira de Zoociências, 9: 137-144.

Sazima, I. \& E. P. Caramaschi. 1989. Comportamento alimentar de duas espécies de Curimata, sintópicas no Pantanal de Mato Grosso (Osteichthyes, Characiformes). Revista Brasileira de Biologia, 49: 325-333.

Schifino, L. C., C. B. Fialho \& J. R. Verani. 1998. Reproductive aspects of Cyphocharax voga (Hensel) from Custódias Lagoon, Rio Grande do Sul, Brazil (Characiformes, Curimatidae). Revista Brasileira de Zoologia, 15: 767-773.

Silva, N. B., H. C. B. Gurgel \& M. D. Santana. 2005. Histologia do sistema digestório de sagüiru, Steindachnerina notonota (Miranda Ribeiro, 1937) (Pisces, Curimatidae), do rio Ceará Mirim, Rio Grande do Norte, Brasil. Boletim do Instituto de Pesca, 31: 1-8

Slotte, A. 1999. Differential utilization of energy during wintering and spawning migration in the Norwegian spring-spawning herring. Journal of Fish Biology, 54: 338-355.

Sparre, P. \& S. C. Venema. 1997. Introdução à avaliação de mananciais de peixes tropicais. Roma, FAO Documento Técnico Sobre as Pescas, 404p.

Teixeira, J. L. A. \& H. C. B. Gurgel. 2004. Dinâmica da nutrição e alimentação natural de Steindachnerina notonota (Miranda-Ribeiro, 1937) (Pisces, Curimatidae), Açude de Riacho da Cruz, Rio Grande do Norte, Brasil. Revista Brasileira de Zoociências, 6: 19-28.

Vari, R. P. 1989. A phylogenetic study of the neotropical characiform family Curimatidae (Pisces, Ostariophysi). Smithsonian Contributions to Zoology, 471: 1-71.

Vari, R. P. 2003. Family Curimatidae - toothless characiforms. Pp. 51-64. In: Reis, R. E., S. O. Kullander, C. J. Ferraris Jr. (Orgs.). Check list of the freshwater fishes of South and Central America Porto Alegre, Edipucrs, 729p.

Vazzoler, A. E. A. M. 1981. Manual de métodos para estudos biológicos de populações de peixes - reprodução e crescimento. Brasília, CNPq, 106p

Vazzoler, A. E. A. M. 1996. Biologia da reprodução de peixes teleósteos: teoria e prática. Maringá, EDUEM, 169p.

Vazzoler, A. E. A. M. \& N. A. Menezes. 1992. Síntese de conhecimentos sobre o comportamento reprodutivo dos Characiformes da América do Sul (Teleostei, Ostariophysi). Revista Brasileira de Biologia, 52(4): 627-640.

Wallace, R. A. \& K. Selman. 1981. Celular and dynamics aspects of ovocyte growth in teleosts. American Zoologist, 21: 325-343.

West, G. 1990. Methods of assessing ovarian development in fishes: a review. Australian Journal of Marine and Freshwater Research, 41: 199-222.

Wootton, R. J. 1992. Fish ecology. New York, Chapman and Hall, $212 \mathrm{p}$.

Zar, J. H. 2010. Biostatistical analysis. $5^{\text {th }}$ edition. New Jersey, Prentice-Hall, 944p.

Submitted August 5, 2011

Accepted September 18, 2012 